\title{
Citra Kawasan Manahan Kota Surakarta Sebagai Lokasi Stabilisasi PKL
}

\author{
The Image of Manahan of Surakarta as a Stabilization Location for \\ Urban Hawkers
}

\section{Murtanti Jani Rahayu ${ }^{1}$, Imam Buchori ${ }^{2}$, Retno Widjajanti ${ }^{2}$, Rufia A Putri ${ }^{1}$, Erma F Rini ${ }^{1}$}

Diterima:, 23 Agustus 2018 Disetujui: 23 November 2018

\begin{abstract}
Abstrak: Stabilisasi PKL oleh pemerintah kota Surakarta, berpengaruh terhadap estetika kawasan. Manahan salah satu lokasi stabilisasi yang dianggap berhasil. Hadirnya PKL stabilisasi mampu menarik pengunjung. Kawasan ini juga lebih mudah diingat oleh pengunjung dibanding kawasan lain yang tidak mengalami stabilisasi. Itu artinya kawasan ini mempunyai kualitas citra yang baik, unik dan mudah dikenang. Tujuan dari tulisan ini, yaitu menggali citra kawasan stabilisasi Manahan berdasarkan metode gabungan dari Lynch, Nasar dan Kotler. Memahami citra kawasan, secara prinsip yang dipergunakan untuk menilai adalah 5 elemen dasar pembentuk citra meliputi landmark, path, edge, district dan node. Kelimanya akan menjadi komponen dalam menilai legibility, imageability, identitas dan visual connection yang akan membentuk kognisi pengunjung sehingga dapat dijadikan sebagai orientasi lingkungan ketika berada di suatu tempat. Pengenalan diawali dengan stimulasi grafis dan visual. Pemetaan/cognitive map dan membuat penilaian familiarity-favorability-semantic differensial. Hasil penelitian, kawasan Manahan mempunyai potensi citra yang baik, sehingga PKL yang ditata dapat terus berkembang dan lokasi penataan menjadi kawasan yang menarik dan mendukung identitas kota Surakarta sebagai kota ramah PKL dengan tetap menjadi kota yang indah dan bersahabat bagi seluruh warga dan wisatawan yang berkunjung.
\end{abstract}

Kata kunci: Stabilisasi PKL, citra kawasan, peta mental

\begin{abstract}
Stabilization of street vendors by the government of Surakarta, that have great implications on the aesthetic style at some city parts. Manahan area is one of the locations of street vendor stabilization that is considered successful to attract visitors. This area is also more easily remembered. It means that this area has good and unique image quality. The purpose of this paper is to explore the image of street vendor Manahan stabilization. Understanding the image of city area, principle that is used to assess the five basic elements: landmarks, path, edge, district and node. All five elements will be the componens in assessing the identity, and meaning that will shape the cognition of visitors so that it can be used as environmental orientation. The introduction of Manahan stabilization area begins with stimulation done by graphic and visual technique before the interviews made a cognitive map in Stabilisasi PKL Manahan area and also made familiarity-favorabilitysemantic differensial assesment. This area has the potential of good image, so that the managed street vendors can continue to grow and the location of the arrangement becomes an attractive area and supports the identity of the city of Surakarta as a merchant friendly city by staying a beautiful and friendly city.
\end{abstract}

Keywords: Stabilization, Image of the area, kognitive map

\footnotetext{
${ }^{1}$ Perencanaan Wilayah dan Kota FT, PIPW LPPM, Universitas Sebelas Maret Surakarta

${ }^{2}$ Departemen Perencanaan Wilayah dan Kota, Fakultas Teknik, Universitas Diponegoro
} 


\section{PENDAHULUAN}

Stabilisasi PKL adalah penataan PKL oleh pemerintah yang menetapkan lokasi yang sama atau lokasi yang tidak terlalu jauh dari lokasi lama sebagai tempat berusaha bagi PKL (Onyango et al, 2012; Rahayu et al, 2013; Rahayu et al, 2018). Lokasi ini berada di ruang publik dapat berupa taman, open space, tepi jalan/sebagian trotoar maupun lapangan sebagai tempat PKL berdagang. Lokasi yang distabilisasi mendapat legalitas, meski aktivitas PKL tetap dianggap sebagai aktivitas informal (Mc Gee \& Yeung, 1977; Kettles, 2007; Rahayu 2016). Penyeragaman sarana dagang, sebutan lain dari stabilisasi menurut Hanifah \& Musadun (2014) bertujuan agar kawasan menjadi lebih teratur dan rapi tanpa mengganggu pengguna ruang publik yang lain. Meski keberhasilan secara ekonomi belum tercapai sepenuhnya, penataan dalam bentuk stabilisasi lebih banyak diminati PKL daripada relokasi (Lince, 2011; Rahayu, 2016). Secara fisik, stabilisasi ini berimplikasi signifikan pada estetika bagian kawasan kota (Rahayu et al, 2013). Beberapa bagian kawasan kota Surakarta telah banyak mengalami perubahan sejak diresmikannya lokasi tersebut yang notabene merupakan ruang publik/fasilitas publik menjadi lokasi berdagang para PKL. Lokasi-lokasi tersebut adalah kawasan/koridor Manahan, Galabo, Kotta Barat, Hasanudin, Wahidin, Supomo, Sriwedari, Mojosongo, Kolangkaling, Komplang, Timur PDAM, Timur Telkom, Sekartaji, Pedaringan, shelter Silir, dekat pasar Notoharjo, Solo Square, Purwosari, dekat pasar Pucangsawit, galabo Pucangsawit, Urban forest dan Jurug, tampak mempunyai kondisi yang berbeda dengan kawasan kota tanpa stabilisasi PKL.

Menurut Rahayu et al (2016) dari sekian banyak lokasi stabilisasi, Manahan mempunyai karakteristik yang sangat unik. Kawasan stabilisasi Manahan pernah ditata pada tahun 1996, kemudian direvitalisasi kembali tahun 2006, karena sudah menurun kualitasnya apalagi berdekatan dengan Stadion Manahan yang menjadi landmark kota Surakarta. Lokasi stabilisasi ini berada di tengah kota dengan tingkat keramaian yang tinggi, berdekatan dengan aglomerasi kegiatan yang sangat beragam karena berada di kawasan mix use. Lokasi stabilisasi PKL Manahan ini juga paling dikenal dari awal penataan sampai sekarang. Kawasan stabilisasi PKL Manahan terbagi menjadi 2 bagian yaitu shelter sebelah barat (shelter KS Tubun) yang terdiri dari 80 an lapak dan shelter sebelah utara (shelter Menteri Supeno) sekitar 180 an lapak. Kehadiran PKL yang telah ditata di kawasan Manahan, mampu menarik pengunjung baik setiap harinya maupun ketika weekend apalagi liburan. Kawasan stabilisasi Manahan juga lebih mudah diingat oleh masyarakat dibanding kawasan lain yang tidak dilakukan stabilisasi. Itu artinya kawasan stabilisasi Manahan mempunyai kualitas citra kota yang unik yang memudahkan bagi pengunjung untuk berorientasi ketika berada disana (Rahayu et al, 2016).

Memahami citra kawasan Manahan, diawali dengan mengidentifikasi 5 elemen pembentuk kawasan. Lima elemen-elemen tersebut adalah node, path, edge, landmark dan district yang akan membentuk kognisi pengunjung/pengamat sehingga dapat dijadikan sebagai orientasi lingkungan ketika berada di suatu tempat (Lynch, 1960). Hal ini untuk menilai legibility, imageability, yang diperoleh dari penilaian identitas dan struktur/visual connection (Rahayu et al, 2016). Citra kawasan kota juga dapat menjadi alat penting dalam memasarkan sebuah kota. Suatu citra kawasan tidak hanya mengenalkan identitas suatu kawasan atau kota yang bertumpu pada daya tarik aspek fisik saja. Citra kota dapat dikembangkan sebagai potensi untuk menarik minat wisatawan, investor maupun penduduk lokal dalam rangka meningkatkan kegiatan ekonomi kota (Kotler,1993). Upaya meningkatkan pemasaran kota (city branding) dapat berdampak pada pertumbuhan ekonomi kota tersebut. Hal ini tidak terlepas dari ekonomi kerakyatan yang kita kenal dengan PKL sebagai representasi dari sektor informal dan juga representasi dari kota Surakarta (Rahayu et al, 2016).

Kota Surakarta menyadari betul bahwa tidak dimilikinya sumber daya alam, tidak menjadi penghalang untuk membangun kotanya sebagai kota wisata. Hal ini tampak dari berbagai upayanya dalam mengemas kegiatan budayanya menjadi destinasi wisata mulai 
dari batik, kuliner, seni tari sampai dengan seni lukis. Di samping wisata budaya tersebut, upaya penataan PKL menjadi perhatian serius bagi pemerintah Kota Surakarta, karena pertumbuhan PKL yang sulit dikendalikan sehingga mempengaruhi struktur kawasan yang pada gilirannya akan mempengaruhi citra kawasan kota (Rahayu et al, 2016). Untuk itu penting untuk mengetahui bagaimana citra suatu kawasan lokasi stabilisasi dengan melihat elemen-elemen pembentuk citra yang ada, sehingga pada akhirnya suatu kawasan mampu mengarahkan seseorang untuk berorientasi di suatu kawasan lokasi stabilisasi tersebut dengan baik.

Penataan PKL yang telah dilakukan pemerintah Kota Surakarta adalah penataan relokasi dan stabilisasi (Rahayu, 2016). Relokasi memindahkan PKL ke dalam pasar. Status mereka menjadi legal. Dampak relokasi secara fisik, kawasan kota bersih dari PKL namun selanjutnya dapat dilihat, banyak PKL kembali ke tempat semula untuk kembali berjualan. Konsep stabilisasi yang menjadi pilihan lebih banyak PKL menjadi tantangan tersendiri bagi pemerintah. Lokasi yang dipilih tidak jauh dari lokasi PKL semula berdagang, lokasi berada di kawasan strategis dan dapat dipastikan berada di ruang publik (Rahayu, et al 2018). Pilihan ini lebih banyak membawa keberhasilan dari beberapa aspek yaitu aspek fisik, ekonomi dan social, karena tanpa konflik (Rahayu, 2016). Namun ketika lebih banyak stabilisasi dilakukan, tidak selalu membawa tingkat keberhasilan yang sama dengan penerapan konsep stabilisasi pada awalnya. Sebagian besar PKL ada yang keluar dari lokasi stabilisasi dan diganti oleh PKL baru. PKL baik yang telah keluar maupun yang masih bertahan ada yang berkembang maju/evolusi dengan usaha/pekerjaan barunya, namun ada juga yang tetap lemah atau bahkan mengalami kemunduran (involusi).

Mencermati kondisi tersebut, dapat diketahui bagaimana citra kawasan kota dari lokasi stabilisasi yang memiliki tingkat keberhasilan yang baik. Kondisi baik ini diharapkan dapat diterapkan di lokasi yang lain. Citra suatu kawasan diharapkan dapat menghadirkan ingatan pengunjung untuk bisa berorientasi di suatu lokasi sehingga mereka akan nyaman dan tertarik untuk mengunjungi kawasan tersebut dengan keberadaan PKL sebagai elemen citra kota yang sangat menarik.

\section{METODE}

\section{Penilaian Kondisi Lokasi Stabilisasi PKL kota Surakarta}

Penilaian ini bertujuan untuk memilih lokasi stabilisasi yang mempunyai tingkat keberhasilan yang baik dari 24 lokasi yang ada di kota Surakarta. Lokasi-lokasi stabilisasi PKL tersebut adalah (1). Manahan KS Tubun, (2). Manahan Menteri Supeno, (3). SD Kristen Manahan, (4). Hasanudin, (5). Supomo, (6). Sriwedari, (7). Kolang Kaling, (8) Timur PDAM, (9). Solo Square, (10). Galabo, (11). Komplang, (12). Mojosongo, (13) Purwosari, (14). Pucangsawit, (15). Dekat Pasar Pucangsawit, (16). Urban Forest, (17). Jurug, (18). Sekartaji, (19). Pedaringan, (20). Dekat Pasar Notoharjo, (21). Silir, (22). Wahidin, (23). Kotta Barat dan (24). Timur Telkom (lihat gambar 1).

Lokasi dengan nilai paling tinggi berarti lokasi penataan mempunyai tingkat keberhasilan yang baik. Hal-hal yang menjadi pertimbangan/kriteria keberhasilan adalah kondisi-kondisi yang terkait aspek fisik dan non fisik (Rahayu et al, 2016). Aspek-aspek tersebut adalah : jumlah PKL, jumlah konsumen, peningkatan pendapatan, fasilitas yang tersedia, kondisi keramaian, dan aktivitas utama yang didekati. Aspek terakhir merupakan aspek yang dipertimbangkan, namun tidak disertakan dalam perhitungan score.

Dari hasil analisis terhadap 24 kondisi lokasi stabiliasi PKL yang ada di kota Surakarta, lokasi yang mempunyai keberlangsungan tertinggi adalah kawasan stabilisasi Manahan. 


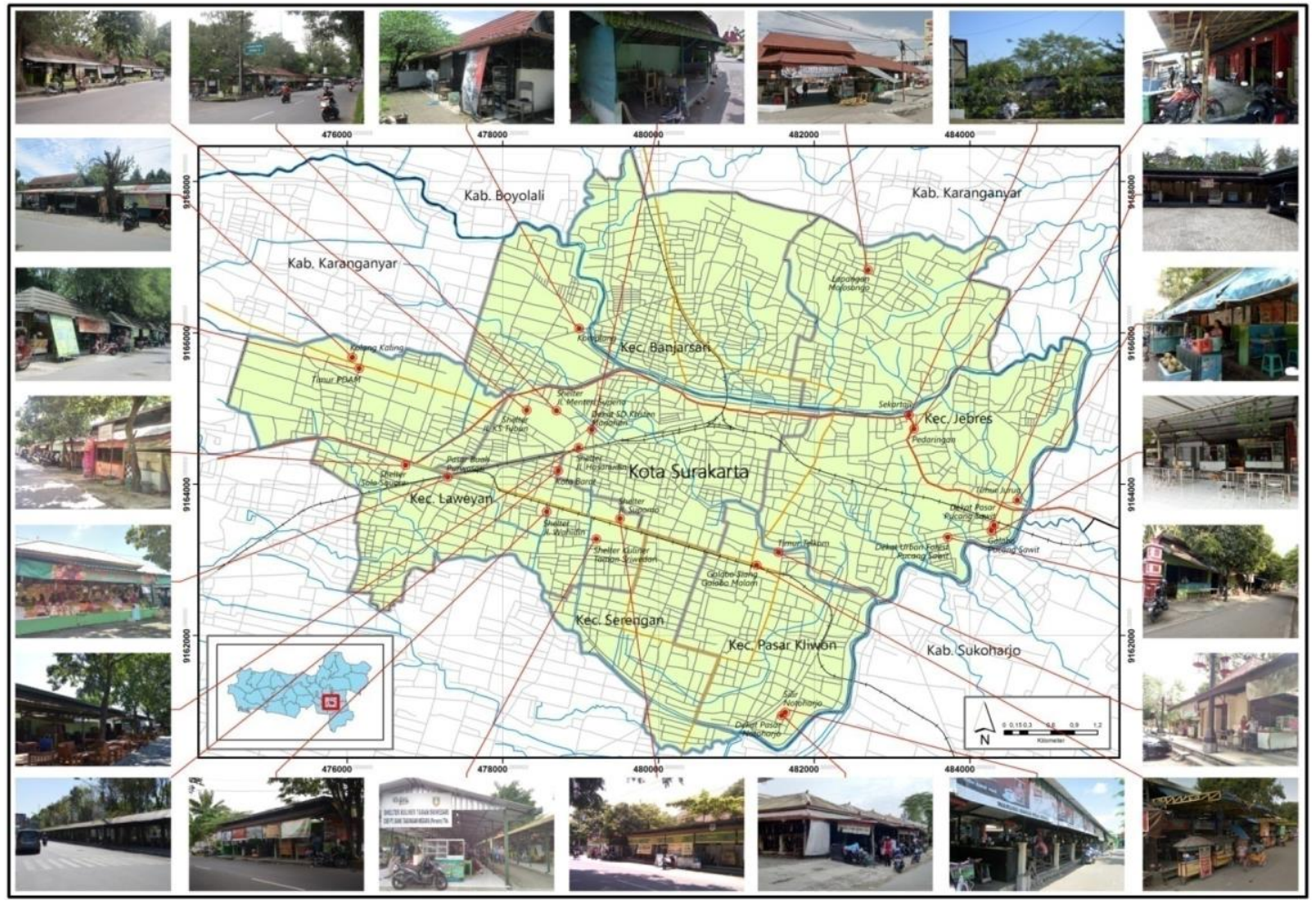

Sumber : Rahayu et al, 2018

Gambar 1 : Peta Persebaran Lokasi Stabilisasi Kota Surakarta

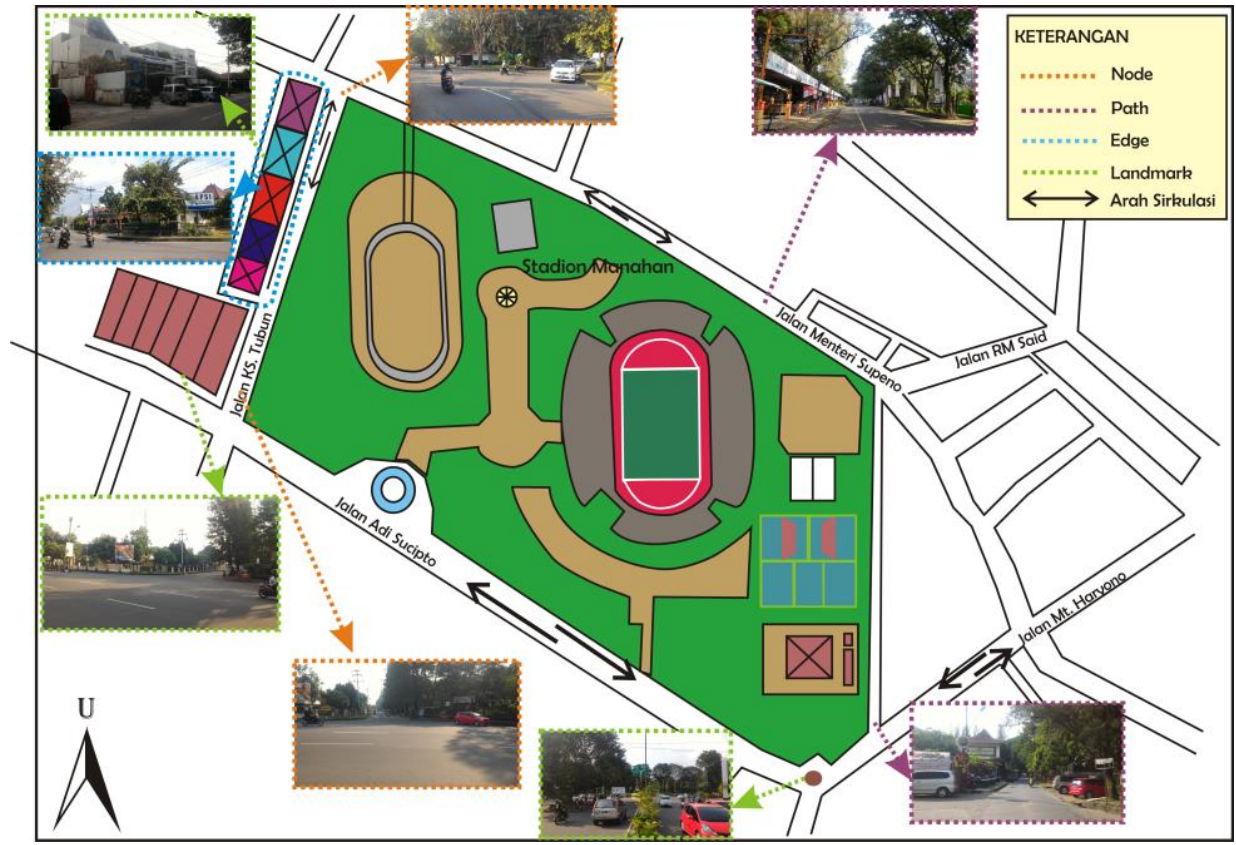

Sumber : Observasi, 2016

Gambar 2 : Kondisi Lingkungan Sekitar Lokasi Stabilisasi Manahan Kota Surakarta 


\section{Narasumber/Pengamat}

Narasumber atau narasumber diambil secara purposive dengan kriteria : mahasiswa program studi Arsitektur dan Perencanaan Wilayah Kota FT UNS yang sudah memperoleh materi kuliah tentang teori citra kawasan, berasal dari Surakarta atau memahami kota Surakarta, frekuensi kedatangan ke lokasi stabilisasi Manahan $>5 \mathrm{x}$ atau paham lokasi stabilisasi Manahan. Berdasarkan kriteria tersebut diambil narasumber sejumlah 30 orang.

\section{Variabel dan teknik analisis}

Tabel 2. Variabel Penelitian

\begin{tabular}{c|l|l|l}
\hline $\begin{array}{c}\text { Elemen citra } \\
\text { kawasan }\end{array}$ & Telaah penilaian citra & Teknik penggalian data & $\begin{array}{c}\text { Alat pengumpulan } \\
\text { data/informasi }\end{array}$ \\
\hline & - Legibility & - Familiarity \& & Kuesioner \\
Elemen path, & - Imageability : & Favorability dan & \\
node, edge, & - Identitas kawasan & Likability & \\
landmark, dan & - Struktur/Visual & - Semantic Differensial & \\
\cline { 3 - 4 } district & Connection & - Peta evaluasi/kognitif & $\begin{array}{l}\text { Gambar peta } \\
\text { sesuai pemahaman }\end{array}$ \\
\hline
\end{tabular}

Sumber: Lynch (1960), Kotler et al (1993), Nasar (1978) disesuaikan, 2016

Metode dan teknik yang dipergunakan dalam menilai citra kawasan Manahan merupakan gabungan dari metode Lynch, Nasar dan Kotler. Metode Lynch (1960) menggali citra kawasan melalui unsur-unsur Imageability yaitu identitas, struktur dan makna dengan menggunakan kognitif map. Menurut Nasar (1978) metode ini sulit diterapkan dan tidak praktis. Nasar mengenalkan suatu cara yaitu dengan mengetahui persepsi rata-rata tentang hal yang disukai dan tidak disukai oleh masyarakat terhadap bagian-bagian atau tempattempat tertentu di sebuah kawasan/likability. Ungkapan emosional seorang pengamat terhadap lingkungannya akan sangat bermakna dalam menilai citranya. Bangunan yang dikenal/mudah diingat di kawasan tersebut akan menimbulkan kesan yang kuat. Jika kebanyakan orang menyukai sebuah elemen kawasan, maka elemen tersebut memiliki citra yang kuat. Namun sebaliknya jika mereka banyak yang tidak menyukai sebuah elemen citra kawasan, maka kawasan akan memiliki citra yang lemah.

Hal ini juga menjadi bagian dari pendapat Kotler et al (1993). Kotler melakukan penilaian citra kawasan berdasarkan persepsi masyarakat dimana lebih menekankan citra kawasan sebagai potensi ekonomi untuk menarik minat pengunjung dalam rangka mendorong bangkitnya perekonomian suatu kawasan. Dalam metode yang disampaikan Kotler et al (1993) menggunakan 3 teknik yaitu: Penilaian keterkaitan dan keadaan mengenal atau tidak (Familiarity-Favorability Measurement). Selanjunya adalah langkah diferensial semantik (Semantic Differential), dimaksudkan untuk menilai rasa orang terhadap suatu tempat atau benda berdasarkan: sangat tidak menyenangkan, agak tidak menyenangkan, tidak tahu, agak menyenangkan, sangat menyenangkan. Penilaian kedua dari Kotler ini menyerupai langkah likability dari Nasar. Langkah ketiga pembuatan peta evaluatif (Evaluative Maps). Metode ini digunakan dalam melakukan penilaian citra kawasan berdasarkan persepsi masyarakat yang digambarkan kedalam peta. Langkah ini sama dengan penyusunan kognitive maps yang dilakukan Lynch.

Citra kawasan menjadi modal yang sangat penting didalam merencanakan, merancang, dan mengelola suatu kawasan. Citra kawasan merupakan unsur yang dapat menghasilkan pengalaman dari ruang suatu kawasan (urban experience). Dengan citra kawasan seseorang mampu memetakan keberadaan dirinya dalam suatu kawasan sesuai pemahamannya. Pembentuk citra kawasan terdiri dari unsur fisik maupun non fisik yang terkandung dalam suatu kawasan. Dalam pengembangan suatu kawasan, citra kawasan 
berperan sebagai pembentuk identitas kawasan dan sebagai penambah daya tarik suatu kawasan (Lynch, 1960).

\section{Tahapan Penilaian Citra Kawasan}

Citra kawasan yang terbentuk oleh persepsi pengunjung melalui tahapan :

1) Stimulus visual/iconic pada tahap pertama dengan menunjukkan kepada narasumber 5 elemen-elemen kawasan stabilisasi Manahan yang ada meliputi path, node, edge, landmark, dan district

2) Stimulus grafis dengan mengajak narasumber membuat peta evaluasi/peta mental terhadap lokasi stabilisasi Manahan yang narasumber pahami

3) Menjawab daftar pertanyaan terkait peta yang sudah dibuat yaitu obyek apa saja yang dikenal, obyek apa saja yang menyenangkan/menarik/disukai, spot mana di kawasan stabilisasi Manahan yang paling dikenal. Selanjutnya citra kawasan akan dikenali dan dianalisis.

\section{HASIL DAN PEMBAHASAN}

\section{Identifikasi objek/elemen pembentuk citra kawasan stabilisasi PKL Manahan}

Hasil dari penggalian persepsi narasumber yang dilakukan dengan stimulus grafis, visual, cognitif map, diperoleh identifikasi obyek-obyek yang dijawab oleh narasumber. Berikut hasil identifikasi objek berdasarkan teknik familiarity-favorability measurement dan semantic differentia/likabilityl, serta evaluatif maps/cognitif maps.

\section{Objek yang Dikenal}

Berdasarkan hasil kuesioner yang dilakukan pada mahasiswa Arsitektur dan PWK UNS, di Manahan terdapat 52 objek yang teridentifikasi. Berdasarkan tingkat dikenalinya objek-objek tersebut (Familiarity-Favorability Measurement) terdapat 14 tingkat/peringkat objek dikenal. Objek yang paling dikenali adalah PKL Manahan, Lapangan Manahan, Kantor Polres Kota Surakarta, dan SMAN 4. Objek yang dikenali antara lain: Cafedangan, Patung Obor, UNS PJOK, Kantor Dsihubkominfo, Kolam renang Tirtomoyo. Objek yang paling tidak dikenali antara lain: Patung Kuda, FIS, Kalam Kudus, SMPN 1, Gedung Wanita, Patung Manahan, Pos polisi, Pom Bensin, Pedestrian J1. Adi Sucipto, Sofie shoufle, Bundaran POM Manahan, Bubur Ayam Sekawan, Primagama, Balekambang, APSI, PDAM, Kantor Pajak Pratama, Patung Topeng, Taman Air Mancur, Gedung Warastratama.

Objek-objek yang paling dikenali diatas berada di perempatan/persimpangan jalan. Termasuk didalamnya adalah shelter PKL. PKL Manahan merupakan kawasan kuliner yang banyak didatangi pengunjung. PKL Manahan ini merupakan PKL yang ditata berjajar di utara dan barat Stadion Manahan. Kawasan ini setiap hari buka dari pagi hingga malam hari dan selalu ramai. Namun, akan menjadi lebih ramai di hari Sabtu dan Minggu karena banyak orang yang berolaharaga, menghabiskan waktu akhir pekan atau berbelanja di Sunday Market Manahan. Kawasan PKL ini dekat dengan Polres Surakarta dan SMA N 4 Surakarta.

Hal ini sesuai dengan pendapat Mc Gee \& Yeung (1977) dan Widjajanti $(2009,2012)$ bahwa kecenderungan PKL memilih lokasi di persimpangan yang banyak lalu lalang orang dan lalu lintas. 


\section{Objek menarik/menyenangkan/disukai}

Berbagai objek di sekitar Manahan yang telah teridentifikasi melalui, selanjutnya akan dinilai objek-objek yang menarik/disukai pengamat. Berdasarkan hasil yang diperoleh, terdapat 29 objek dengan tingkat kemenarikan beragam. Objek yang paling menarik atau disukai adalah lapangan Stadion Manahan dan PKL Manahan. Objek yang paling tidak menarik adalah Hello Solo, SD-SMP Kalam Kudus, Megatron, Bundaran Manahan, SPBU Manahan, SMP 1, Balekambang, Kolam Renang Tirtomoyo, Patung Topeng, UPT Kebersihan Pertamanan, Taman Air Mancur, dan SMKN 2. Deretan PKL dan stadion Manahan menjadi objek yang paling menarik menurut pengunjung karena objek itu yang menjadi tujuan utama mereka datang ke Manahan (Rahayu, 2016). Stadion Manahan menjadi icon kota dan bangunan yang mempunyai fungsi besar serta kesejarahan yang mudah dikenang. Deretan PKL merupakan simbol keberpihakan pemerintah terhadap keberadaan PKL dan adanya subsidi ruang publik bagi PKL (Solo Pos, 28 Juli 2017). Sebagian besar pengunjung menjadikan PKL dan stadion Manahan sebagai tujuan utama datang ke Manahan. Sebagian kecil pengunjung hanya mampir dari atau menuju suatu tempat, artinya PKL di sini bukan menjadi tujuan utama/menjadi tujuan sampingan (Rahayu, 2016).

\section{Penilaian citra kawasan stabilisasi PKL Manahan}

Citra kawasan Manahan ini akan ditelaah dari objek-objek yang telah diidentifikasi diatas melalui legibility dan imageability. Dari keduanya dapat diketahui identitas kawasan dan struktur/visual connection yang memperkuat kesan dan gambaran kawasan.

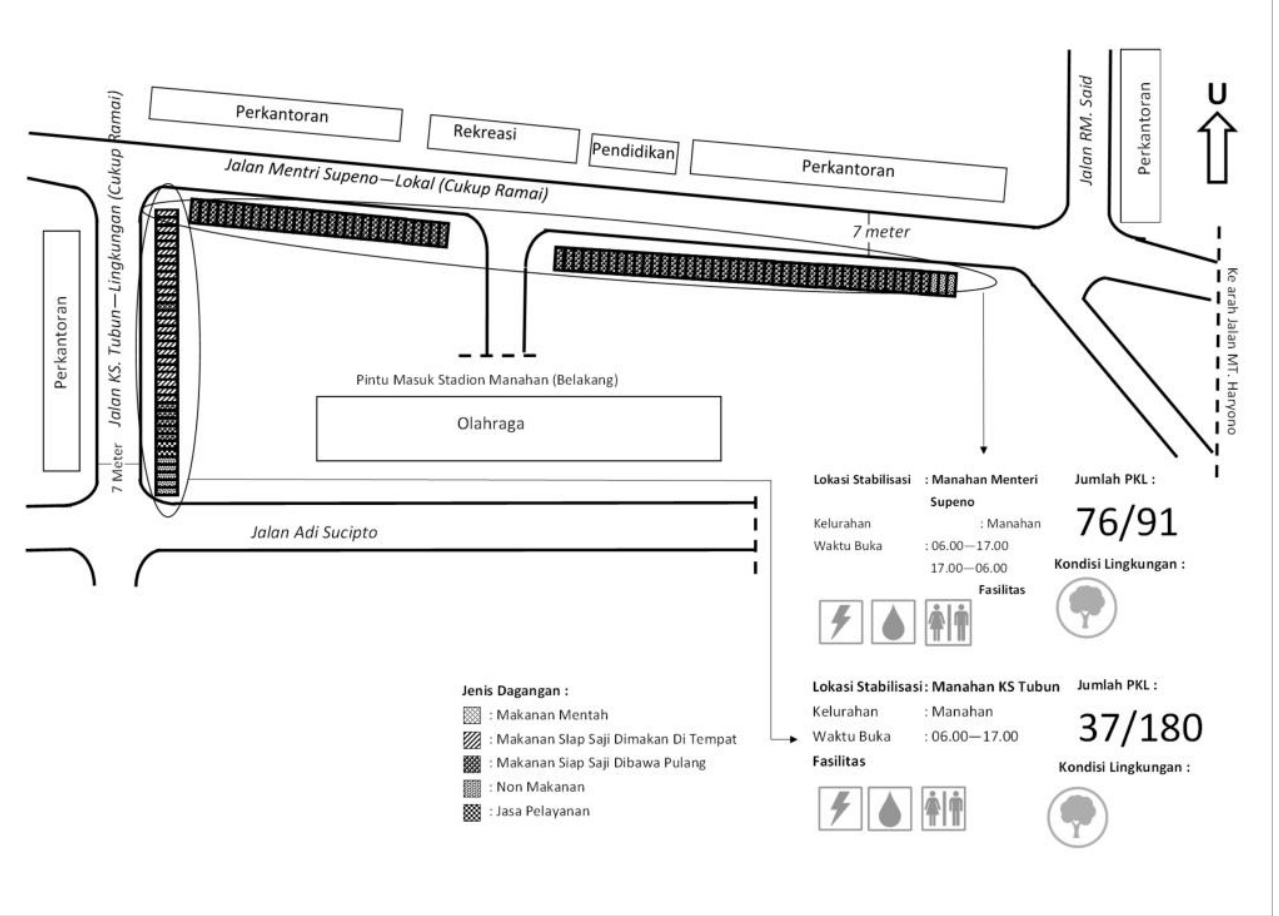

Sumber : Hasil Olah Data, 2018

Gambar 3. Karakteristik Lokasi Stabilisasi Manahan Supeno dan KS Tubun 
Rahayu, Buchori, Widjajanti, Putri, Rini

\section{Legibility}

Legibility menunjukkan kemampuan kawasan mendatangkan kesan. Kesan terhadap kawasan terbentuk dari berbagai elemen pembentuk citra, yaitu path/jalur), edge/tepian, district/ kawasan, node/simpul dan landmark/tetenger (Lynch, 1960). Pada kenyataannya kelima elemen tersebut merupakan referensi yang digunakan dalam mengidentifikasi pembentuk citra kawasan berdasarkan elemen fisik. Berikut adalah elemen beserta objek yang mampu membangkitkan citra di kawasan Manahan menurut narasumber, yaitu :

1) Path: Jl Adisucipto, KS Tubun dan Menteri Supeno

2) Edges : Polres, Stadion Manahan

3) Landmark: Stadion Manahan, Patung Obor

4) Node : Lokasi PKL, Polres, Stadion Manahan, SMA 4 Surakarta

5) District : Stadion Manahan, Polres

Keberadaan Stadion Manahan sebagai fasilitas publik bertaraf Nasional bahkan Internasional dianggap masyarakat sebagai landmark karena sangat dikenal masyarakat luas. Stadion ini sangat menentukan kesan yang diperoleh pengunjung terhadap kawasan Manahan yang merupakan warisan era orde baru, disamping objek patung obor Manahan. Menurut Luque et al (2007) keberadaan objek warisan digolongkan sangat penting. Citra warisan menjadi nilai jual, disamping itu membangkitkan emosi dan visualisasi. Keberadaan stadion Manahan dan patung Obor meski bukan objek heritage dunia namun menjadi objek warisan sejarah Indonesia yang sangat membanggakan. Mampu membangkitkan emosi masa lalu dan juga penampilannya secara fisik mendukung kawasan Manahan sebagai kawasan andalan kota Surakarta. Selain sebagai landmark, stadion Manahan juga dianggap masyarakat sebagai edge, node dan distric.

Deretan PKL sendiri oleh pengunjung dianggap sebagai node selain kantor Polres, stadion dan SMA 4 yang semakin memperkuat kesan yang diperoleh, karena karakter aktivitas yang dilakukan sangat khas, berbeda dengan aktivitas lain yaitu dengan adanya konsumen yang keluar masuk di kawasan ini. Kepuasan dan kesenangan masyarakat ketika berkunjung di kawasan Manahan menandakan bahwa deretan PKL mampu membantu pengunjung memperoleh kesan tentang kawasan ini (Andrews, 2001). Artinya selain stadion Manahan, shelter PKL memenuhi aspek legibility. Kantor polres dan stadion juga dianggap oleh pengunjung sebagai distrik karena luasan yang sangat besar dibanding objek lainnya.

Dalam konteks kota, Shirvani (1985) mengungkapkan terdapat beberapa unsur pembentuk kota seperti massa bangunan, tata guna lahan, parkir, pedestrian dan termasuk didalamnya adalah PKL sebagai bagian dari unsur yang mendukung aktivitas (activity support) suatu kawasan. Senada yang disampaikan oleh Manning \& Effendi (1996) bahwa keberadaan PKL merupakan pendukung kegiatan dan mempunyai peran sebagai activity support, sehingga tercipta kualitas ruang kawasan yang dinamis.

Objek-objek dalam kawasan ini juga membentuk sebuah blok/massa bangunan, yang mampu memandu pengunjung mengenali kawasan Manahan secara keseluruhan. Berikut adalah gambaran blok yang dikenali di Manahan beserta objek yang memudahkan berorientasi pada blok tersebut (lihat gambar 2).

\section{Imageability}

Imageability merupakan kemampuan suatu kawasan untuk mudah dibayangkan (Lynch, 1960). PKL Manahan merupakan deret penjual kuliner yang berada diluar stadion Manahan. Deret PKL ini dimaknai pengunjung sebagai node, bisa datang dan pergi dari tempat ini. Kawasan PKL ini cukup dikenal oleh masyarakat kota Surakarta sekitarnya karena berada di pusat kota Surakarta dengan jumlah PKL yang banyak pada deretan shelternya yang sangat panjang membentuk letter L (lihat gambar 1). Kawasan Manahan sebagai landmark kota Surakarta, sangat sering dikunjungi orang baik dari luar kota Surakarta 
maupun orang dalam kota Surakarta. Keberadaan PKL yang dekat dan langsung terlihat oleh pengunjung sangat mudah dijangkau sehingga dikatakan lokasi stabilisasi PKL Manahan berada pada lokasi yang sangat strategis (Rahayu et al, 2016). Pengunjung tidak kesulitan untuk mencapai lokasi, karena letaknya di bagian luar/mengelilingi stadion Manahan. Lokasi PKL ini juga langsung terlihat oleh pengunjung tanpa terhalang oleh bangunan ataupun aktivitas lainnya sebagai syarat keberadaan PKL (Widjajanti, 2009). Kondisi ini sangat mudah diingat bagi pengunjung sehingga dapat dikatakan bahwa citra kawasan Manahan baik karena keberadaan obyek-obyek terlihat dan mudah untuk diingat/dibayangkan. Menurut Lynch (1960), citra kawasan yang jelas akan memberikan banyak hal yang sangat penting bagi masyarakatnya, seperti kemampuan untuk berorientasi di dalam kawasan, identitas yang kuat terhadap suatu tempat, dan adanya keselarasan hubungan dengan tempat-tempat yang lain, yang menunjukkan keindahan lokasi/lingkungan penataan. Hal ini sejalan dengan kondisi kawasan PKL Manahan.

Empat objek yang sangat dikenali yakni Stadion Manahan, shelter PKL, Polres dan SMA 4 Surakarta menunjukkan bahwa objek-objek ini sangat jelas dan mudah diingat. Hal ini dikarenakan objek-objek tersebut mempunyai fungsi sebagai nodes, bersifat publik, berukuran besar dan spesifik serta mempunyai keunikan. Objek yang dikenali adalah Cafedangan, Patung Obor, UNS PJOK, Kantor Dishubkominfo, Kolam renang Tirtomoyo. Patung obor disini dimaknai pengunjung sebagai landmark kota selain stadion Manahan. Sisanya, yakni 44 objek, termasuk dalam kategori tidak dikenali. Objek yang sangat dikenali, dikenali dan tidak dikenali mempunyai perbedaan yang jelas dengan objek yang lain. Hal ini menunjukkan bahwa objek-objek tersebut mempunyai kejelasan sebagai elemen kawasan yang mudah diingat dan dapat menjadi orientasi bagi pengunjungnya.

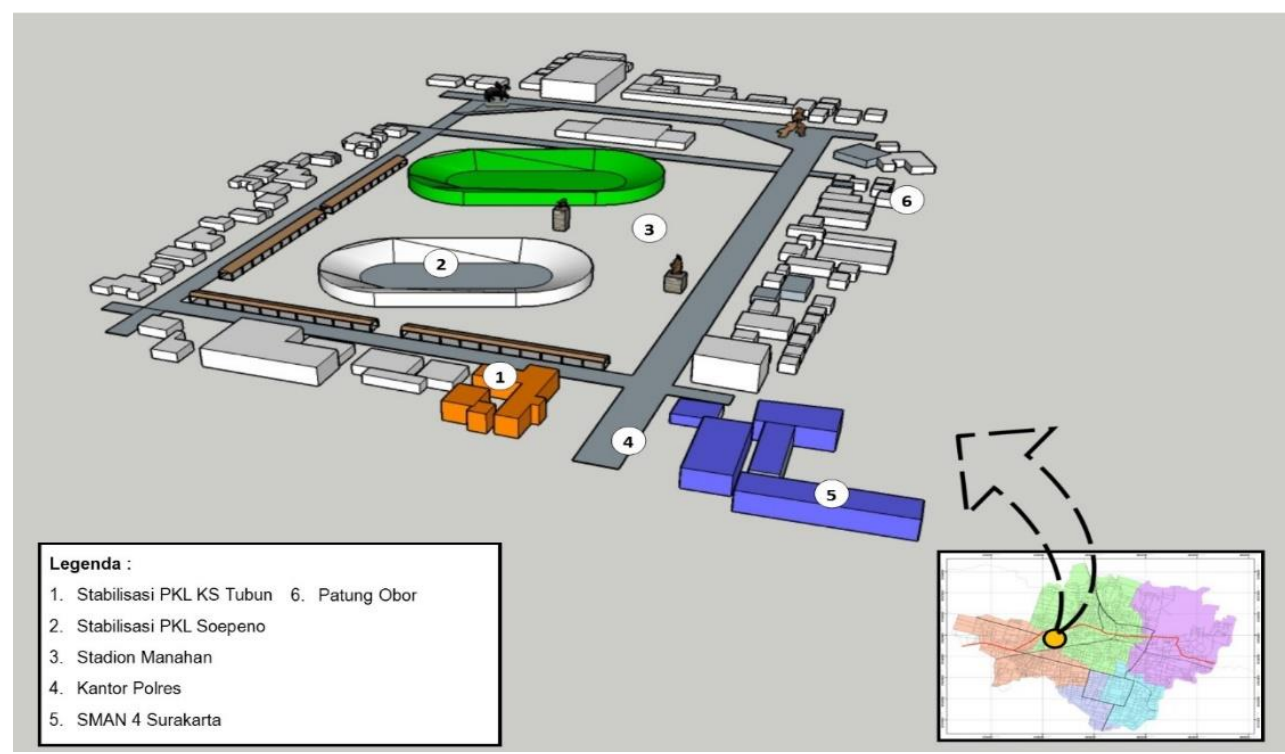

Sumber: Analisis Peneliti, 2016

Gambar 4. Blok-blok bangunan di sekitar Kawasan PKL Manahan

\section{Identitas}

Penilaian legibility dan imageability dapat menunjukkan identitas suatu kawasan. Dari 29 objek yang teridentifikasi, yang masuk dalam kategori sangat menarik adalah Stadion Manahan dan shelter PKL. Keduanya disebut pengunjung dapat menjadi identitas kawasan sekaligus identitas kota. Sisanya, 27 objek termasuk dalam objek menarik seperti patung obor 
sebagai landamark kota. Objek tidak menarik seperti kolam renang Tirtonadi dan FPOK UNS. Stadion Manahan dinilai sangat menarik karena ukurannya besar, memiliki nilai historis (tempat pertama PON), tempat aktivitas rekreasi/olah raga/budaya dan khususnya keberadaan PKL yang menempel mengelilingi stadion. Dimilikinya keterkaitan stadion Manahan dan shelter PKL menunjukkan susunan objek yang dapat memperkuat keberadaannya sebagai identitas kota. Oleh pengunjung Stadion Manahan dimaknai sebagai landmark sekaligus node. Keberadaan shelter PKL sebagai node, semakin mendukung aktivitas ekonomi dan aktivitas rekreasi kota Surakarta.

Perubahan status keberadaan PKL di ruang kota ini menunjukkan bahwa dari elemen yang tidak diinginkan/out of place (Yatmo, 2008; Sarmiento, 2015), kemudian di kawasan ini berubah menjadi identitas kota/in place element dikarenakan adanya pemahaman dari para pengambil kebijakan untuk melihat PKL sesuai dengan konteks lokasi dimana dia mampu tumbuh berkembang (Yatmo, 2008). PKL sebagai identitas lokal kota Surakarta menjadi potensi yang penting untuk dipertimbangkan keberadaannya, sehingga akan selalu diakomodir dalam setiap perencanaan kota. Kondisi seperti di kawasan Manahan ini menunjukkan bahwa subsidi ruang publik bagi PKL menjadi sebuah bukti bahwa PKL pantas diakomodir dan ditata (Rahayu-Solopos, 2017).

Kedua objek diatas dapat menjadi identitas kawasan Manahan, juga dengan melihat keterkaitannya dengan objek yang lain terutama patung obor, kolam renang dan fakultas olah raga UNS. Keberadaan Stadion Manahan mendorong kemunculan aktivitas sosial dan komersial yang mendukung dan didukung olehnya. Keberadaan shelter PKL yang menjadi identitas keberadaan PKL yang menarik di kota Surakarta, menjadi penguat kawasan ruang publik Manahan, sehingga aktivitas-aktivitas komersial baik formal maupun informal juga turut hadir di sekitarnya. Susunan dari objek-objek ini sangat berperan dalam menuntun ingatan pengunjung pada kawasan Manahan yang baik, meski banyak objek yang kemudian berubah fungsinya. Lingkungan yang dapat dikenal dengan baik, dapat menjadi citra kawasan yang baik pula. Citra kawasan Manahan juga mengambarkan suatu persamaan dari sejumlah gabungan atau satuan informasi yang melekat dengan tempat tersebut (Kotler et al, 1993).

\section{Visual connection}

Visual connection menunjukkan hubungan yang terbentuk oleh kesamaan tampilan fisik antara bangunan dalam kawasan, sehingga menimbulkan image tertentu. Menurut narasumber, visual connection/struktur yang terbentuk pada kawasan Manahan ini adalah karena adanya koridor/jalan KS Tubun, Menteri Supeno dan Adi Sucipto yang dimaknai pengunjung sebagai path. Deretan PKL yang berada di path-path tersebut sekaligus mengelilingi Stadion Manahan dalam lingkungan yang teduh dan hijau dengan desain yang berbau budaya Jawa. Kondisi teduh dan hijau juga tampak di sepanjang koridor lain di sekitar Manahan. Koridor jalan dimana PKL berada, terlihat berbeda dari koridor lain di sekitar kawasan Manahan. Hal ini justru menunjukkan keunikan koridor ini dibanding koridor di sekitarnya. Path koridor Adi Sucipto tampil sebagai penghubung penampilan kawasan secara keseluruhan sehingga seluruh koridor di kawasan Manahan tampak serasi saling melengkapi karena path koridor Adi Sucipto yang sangat luas, bertemu dengan path koridor KS Tubun yang sangat sempit. Kondisi ini akan dapat mendorong kawasan Manahan sebagai city branding, karena keunikannya dibanding dengan kawasan yang lain (Ashworth, 2009).

Keunikan dari PKL dapat dilihat dari bagaimana karakter aktivitas yang terjadi yang dipengaruhi karakter berlokasinya (Mc Gee \& Yeung, 1977). Pertama terkait jenis dagangan PKL yang didominasi makanan siap saji semakin memperkuat citra kawasan PKL Manahan sebagai kawasan kuliner pendukung aktivitas utama Manahan yang mempunyai kekhasan. Hubungan antara suatu aktivitas pendukung dengan fungsi aktivitas utama dapat memberikan citra visual yang spesifik pada kawasan-kawasan tertentu, karena dapat 
menghadirkan identitas lokal dan aktivitas yang khas suatu kawasan/bagian kota. Selain jenis dagangan, penampilan dagangannya melalui sarana dagang dan juga luasan lapaknya dapat mendukung kesan yang diperoleh pengunjung secara langsung sekaligus sebagai penghubung dari penampilan kawasan Manahan secara keseluruhan.

Terkait dengan lokasi stabilisasi, menjadi aspek paling penting dalam aktivitas PKL (Mc Gee \& Yeung, 1977). Di dalam penataan dan pengelolaan PKL, aspek karakter berlokasi PKL dapat dilihat dari kedekatan dengan aktivitas utama, keramaian lokasi/jalan, kedekatan dengan rumah PKL, kestrategisan lokasi yang dekat dan terlihat, kondisi lingkungan, kemudahan aksesibilitas, pengelompokan pedagang, keamanan, kebersihan, kenyamanan dan ketersediaan sarana dan prasarana seperti air bersih, listrik, TPS dan parkir (Mc Gee \& Yeung, 1977; De Soto, 1991, Werdiningtyas et al, 2012; Sari, 2003; Widjajanti, 2009; Novelia \& Sarjito, 2015; Rahayu, 2016).

Lokasi stabilisasi Manahan, berada di dekat aktivitas rekreasi, olahraga, perkantoran dan pendidikan. Itu artinya lokasi stabilisasi Manahan mendekati pusat aktivitas utama dan aglomerasi aktivitas yang sangat beragam. Jalan di dekat lokasi stabilisasi Manahan dalam kondisi ramai baik jalan lokal Menteri Supeno maupun jalan lingkungan KS Tubun. Dua hal ini sesuai dengan pendapat Bromley (Manning \& Effendi, 1996) bahwa PKL pada umumnya berada di daerah-daerah yang paling menguntungkan di wilayah pusat kota yang penuh orang. Hal ini juga sesuai dengan pendapat Mc Gee \& Yeung (1977) bahwa PKL cenderung untuk beraglomerasi/berkonsentrasi pada area dengan kepadatan populasi yang tinggi pada titik-titik persimpangan transportasi, atau berdekatan dengan aktivitas-aktivitas lain. Letak lokasi yang berada di tengah kota, sangat mudah dijangkau oleh para pedagang yang sebagian besar rumahnya berada di kota Surakarta (Rahayu et al, 2017). Dipilihnya ruang publik yang berupa trotoar/pedestrian oleh PKL di Manahan sesuai pendapat yang diungkapkan oleh Ayeh et al (2011) dan Adedeji (2014) bahwa PKL di Ghana dan Nigeria pada umumnya memilih ruang publik utamanya trotoar/pedestrian.

Deretan PKL berada tepat di pinggir jalan yang mengelilingi stadion Manahan dan merupakan bagian dari trotoar, sehingga sangat dekat dan langsung terlihat oleh pengunjung. Artinya lokasi PKL ini sangat strategis. Selain itu kondisi lingkungan disekitar Manahan juga tampak indah/baik, karena banyak terdapat pohon yang tertata di sepanjang jalan dan juga terdapat berbagai aktivitas olah raga yang mendukung dan didukung oleh keberadaan PKL, mereka saling melengkapi dan memperkuat ruang publik (Shirvani, 1985).

Dalam hal pengelompokan pedagang, pemerintah melakukan penataan secara acak, sehingga pedagang makanan siap saji bisa berdekatan dengan pedagang sejenis maupun tidak sejenis. Kondisi ini menjadikan PKL merasa diperlakukan sama, dan pengunjung juga tidak merasa kesulitan dengan bercampurnya PKL dengan berbagi jenis dagangan. Dari sisi keamanan, kenyamanan dan kebersihan, lokasi stabilisasi Manahan sangat baik. Terkait ketersediaan sarana dan prasarana, lokasi ini mempunyai sumber air bersih dari PDAM. Fasilitas listrik juga tersedia, sedangkan parkir on street di shelter Menteri Supeno cukup leluasa, tanpa mengganggu lalu lintas jalan. Bak sampah juga tersedia dengan waktu pengambilan sampah secara periodik oleh petugas kebersihan.

Dari uraian diatas tampak bahwa kondisi lokasi stabilisasi PKL di kawasan Manahan memiliki aspek budaya, sejarah, pertumbuhan ekonomi dan pembangunan sosial, infrastruktur dan arsitektur, lansekap dan lingkungan yang dapat diterima semua orang. Menurut Zhang (2009), hal ini menunjukkan citra kawasan Manahan yang baik, karena mempunyai peran yag sangat banyak dalam berbagai aspek.

Dari metode yang dipakai dalam penelitian ini tampak, bahwa metode yang dipergunakan Lynch (1960), Nasar (1978) maupun Kotler et al (1993) saling melengkapi dan mempermudah dalam menggali citra kawasan. Legibility dan imageability dapat diperoleh melalui proses identifikasi obyek yang menarik/menyenangkan/disukai yang juga diperkuat melalui peta evaluatif/peta mental yang menunjukkan obyek-obyek yang dimaksud sehingga dapat diketahui obyek-obyek kawasan yang dapat menjadi identitas sekaligus obyek-obyek 
yang muncul sebagai simbol koneksi atau membentuk pola susunan tertentu/struktur kawasan.

Citra kawasan stabilisasi PKL Manahan yang diperoleh diatas, menunjukkan kualitas karakter tempat karena pengunjung merasa kawasan tersebut memberikan perasaan emosional tertentu. Hal inilah yang oleh Nasar dikenal dengan istilah meaning. Perasaan emosional manusia terhadap elemen kawasan inilah yang kemudian menentukan citra kawasan Manahan. Jadi yang paling utama dalam mengidentifikasi citra kawasan adalah bagaimana mengidentifikasi obyek-obyek yang mampu membangkitkan emosi pengunjung. Jika kebanyakan orang menyukai sebuah elemen kawasan, maka elemen tersebut memiliki citra yang kuat. Namun sebaliknya jika mereka banyak yang tidak menyukai sebuah elemen kawasan, maka kawasan akan memiliki citra yang lemah.

\section{Peran PKL Stabilisasi Kawasan Manahan terhadap Citra Kawasan}

Deretan PKL stabilisasi menjadi pendukung terbentuknya citra kawasan Manahan yang baik bagi pengunjung. Hal ini relevan dengan pendapat Maska (1981). PKL mempunyai peran langsung dalam mempengaruhi sebuah citra kawasan, baik maupun buruk (Luque et al, 2007, Adedeji, 2014). Beberapa pengaruh baik dan buruk secara langsung keberadaan PKL stabilisasi Manahan antara lain :

a). Secara fisik, sering menimbulkan kemacetan arus lalu lintas di sekitar PKL stabilisasi Manahan, juga bagi pejalan kaki akan merasa terganggu karena harus berjalan di daerah milik jalan, meski masih ada sebagian trotoar yang diperuntukan bagi pejalan kaki yang berarti ruang publik trotoar dibagi antara PKL dan pejalan kaki (Carr \& Lynch, 1981).

b). Sebagai sebuah fungsi sosial, PKL menjalankan fungsi sosial yang sangat besar. PKL dapat menghidupkan dan membuat kota selalu semarak, tidak sepi, dan dinamis. Dalam pola dan sistem tertentu, aktivitas pedagang kaki lima merupakan daya tarik tersendiri bagi sebuah kota.

c). Dari sudut budaya, PKL menjadi pengemban budaya, yaitu merepresentasikan gejala budaya bagi sebuah kota dan mengenalkan berbagai corak budaya kota tertentu. PKL dapat menampilkan identitas tertentu suatu kota.

\section{KESIMPULAN}

Dari beberapa hal diatas, dapat disimpulkan bahwa kawasan Manahan sebagai lokasi stabilisasi PKL mempunyai nilai citra yang baik menurut pengamat/pengunjung. Stadion Manahan dan patung obor Manahan sebagai landmark utama kawasan Manahan, mampu membentuk identitas kawasan, memberikan kesan mendalam sehingga membuat pengunjung mampu berorientasi di kawasan tersebut. Keberadaan deretan PKL berperan sebagai node di kawasan Manahan dengan aktivitas yang khas dan menjadi tujuan utama oleh sebagian besar pengunjung. Keberadaan PKL ini kawasan ini sudah sangat dipahami dan disukai oleh pengunjung karena kenyamanan dan keindahan lokasi sehingga dapat mendukung pemahaman mereka akan citra kawasan Manahan.

PKL sebagai activity support dapat mendukung aktivitas utama di sekitarnya, menghidupkan dan membuat kota selalu semarak, tidak sepi, dan dinamis sehingga mampu memperkuat karakter ruang publik kawasan Manahan. PKL dapat berpengaruh langsung pada pembentukan citra kawasan yaitu dari tempat beraktivitasnya PKL/lokasi, penampilan fisik tempat usaha/sarana dagang dan penempatan sarana pendukung dan berbagai prasarananya. Karakteristik PKL Manahan lebih banyak menampilkan kesan visual positif. 


\section{UCAPAN TERIMA KASIH}

Terima kasih kepada LPDP, PDIAP UNDIP, PWK FT, PIPW LPPM UNS, dan terkhusus teman-teman yang telah banyak berkontribusi: Rr Ratri Werdiningyas, ST,MT dan Isti Andini, ST,MT atas dukungannya dalam proses penelitian dan penyusunan berbagai artikel publikasinya. Semoga penelitian ini bermanfaat bagi keilmuan dan masyarakat.

\section{DAFTAR PUSTAKA}

Adedeji. J. A, Fadamiro, J.A, Adeoye, A.O. 2014. Spatial Implications of Street Trading in Osogbo Traditional City Centre, Nigeria, Architecture Research, Vol. 4 No. 1A, 2014, pp. 34-44.

Andrews, C.J. 2001. Analyzing Quality-of- place . Environment and Planning B: Planning and Design, Vol.28. No 2, 201-217.

Ashworth,G.J. 2009. The Instrument of Place Branding. How is it done? European Spatial Research and Policy. Vol.16, No.1, 9- 22.

Ayeh, S. Emefa, King, B. Sylvana, R. Nelson, D. Isaac. 2011. Street Vending And The Use Of Urban Public Space In Kumasi. Ghana. The Ghana. Surveyor Journal. Vol. 4, No. ,1., 20-31

Carr, S. \& Lynch, K. (1981). Open Space: Freedom and Control. London: The Smithsonian Institution.

De Soto, H. 1991. Masih Ada Jalan Lain, Alih Bahasa Masri Maris. Penerbit. Yayasan Obor Indonesia.

Hanifah, U. \& Mussadun. 2014. Penilaian Tingkat Keberhasilan Relokasi PKL di Kawasan Pasar Waru dan Simpang Lima. Jurnal Perencanaan Wilayah dan Kota SAPPK ITB dan IAP, Vol. 25, No. 3. 228-242.

Kettles, G.W. 2007. Legal Responses to Sidewalk Vending : The Case of Los Angeles, California dalam Street Entrepreneurs People, Place and politics in local and global perspective. Routledge, New York. 58-78

Kotler, P., Haider D., Rein, I. 1993. Marketing Places.Attracting Investmen, Industry and Tourism to Cities, States, and Nations. New York :Maxwell Macmillan Int.

Lince, Sarah. 2011. The Informal Sector in Jinja, Uganda:Implications of Formalization and Regulation. African Studies Review, Vol 54, No. 2, 73-93.

Luque-Martinez, T., Del Barrio-Garcia, S., Ibanez-Zapata, J. A. and Molina, M. A. R. 2007, Modelling a City's Image: The Case of Granada. Cities. Vol 24, No. 5, 335-352.

Lynch, Kevin, 1960. The Image of The City. Penerbit. MIT Press, MA.

Manning, C and Effendi. 1996. Urbanisasi, Pengangguran dan Sektor Informal di Kota. Penerbit. Yayasan Obor Indonesia.

Maska, Tata, 1981. Citra Sebuah Kota Ditentukan Oleh Penampilan Kawasan Pusat Kotanya.

Mc. Gee, T. G and Yeung, Y. M. 1977. Hawkers In Southeast Asian Cities: Planning for The Bazaar Economiy. Canada: International Development Research Centre.

Nasar, Jack L. 1978. The Evaluative Image Of The City. California : Sage Publications, Inc.

Novelia, A. S., \& Sardjito. 2015. Kriteria Penentuan Lokasi Pedagang Kaki Lima Berdasarkan Preferensi Pedagangnya di Kawasan Perkotaan Sidoarjo. Jurnal Teknik ITS, Vol 4, No. 1, C 28 - C 32.

Onyango, J. O., Onyango., L., and Olima, W. 2012. Dynamics of Street vending Phenomenon in the Kisumu Municipality. Kenya. International Journal of Arts and Commerce, Vol. 1 No. 4, 107-120

Purwanto, E., 2001. Pendekatan Pemahaman Citra Lingkungan Perkotaan (melalui kemampuan peta mental pengamat). Dimensi Teknik Arsitektur Universitas Petra Surabaya Vol. 29, No. 1, Juli, 85-92

Rachbini, D. dan Hamid. 1994. Ekonomi Informal Perkotaan. Penerbit. LP3ES.

Rahayu, M. J. Werdiningtyas, R. Musyawaroh. 2013. Stabilisasi Sebagai Bentuk Penataan PKL Makanan Siap Saji di Kota Surakarta. Jurnal Tata Loka, Vol. 15, No. 1, 39-52.

Rahayu, M.J., Putri, R.A., Andini, I. 2016. Pengembangan Konsep Stabilisasi PKL berbasis Ekonomi Kerakyatan dalam Mendukung Surakarta sebagai kota Wisata. Surakarta: Universitas Sebelas Maret.

Rahayu, M.J. 2016. Perubahan Kondisi PKL Pasca Penataan Stabilisasi dan Relokasi Di Kota Surakarta. Presented at Sustainable Architecture And Urbanism, 43-59.

Rahayu, M.J. 2017. Subsidi Ruang Publik Bagi PKL. Solo Pos. Retrieved Juli 28, 2017 di http://www.solopos.com/2017/08/01/gagasan-subsidi-ruang-publik-bagi-pkl-837906

Rahayu M J, Buchori I, and Widjajanti R. 2018. Study on characteristics of the location of street vendors' stabilization in Surakarta .IOP Conf. Series 106:1-6.

Rahayu, M.J., Putri, R.A., Rini, E.F. 2018. Sustainable Street Vendor's Spatial Zoning Models in Surakarta. IOP Conf. Series 123 
Sarmiento, H . 2015. The Spatial Politics of Street Vending in Los Angeles. Research \& Policy Brief Number 19 Shirvani, Hamid, 1985. The Urban Design Process. New York : Van Nostran Reinhold Company.

Werdiningtyas, R., Rahayu, M. J., dan Musyawaroh. 2012. Hawkers Behaviour and Characteristic As An Important Factor To Empower Local Economy. Presented at 2nd CONVEEESH \& 13Th SENVAR International Conference. Yogyakarta : Architecture Department DWCU.

Widjajanti, R. 2009. Karakteristik Aktivitas Pedagang Kaki Lima Pada Kawasan Komersial Di Pusat Kota, Studi Kasus: Simpang Lima, Semarang. Jurnal Teknik, Vol. 30, No. 3, 162-170.

Yatmo, Y. A. 2008. Street Vendors as 'Out of Place' Urban Elements. Journal of Urban Design, Vol. 13, No.3, 387402.

Zhang,L.\& Zhao S.X. 2009. City branding and the Olympic effect: A case study of Beijing. Cities, Vol. 25, 245254. 